\title{
Physical, mechanical and energy characterization of wood pellets obtained from three common tropical species
}

\author{
Carrillo Parra Artemio ${ }^{1}$, Ngangyo Heya Maginot Corresp., 2 , Colín-Urieta Serafín ${ }^{3}$, Foroughbakhch Pournavab \\ Rahim $^{2}$, Rutiaga Quiñones José Guadalupe ${ }^{3}$, Correa-Méndez Fermín ${ }^{4}$ \\ 1 Instituto de Silvicultura e Industria de la Madera, Universidad Juárez del Estado de Durango, Durango, Mexico \\ 2 Facultad de Ciencias Biológicas, Universidad Autónoma de Nuevo León, San Nicolás de los Garza, Nuevo León, Mexico \\ 3 Facultad de Ingeniería en Tecnología de la Madera, Universidad Michoacana de San Nicolás de Hidalgo, Morelia, Michoacan, Mexico \\ 4 Desarrollo Sustentable, Tecnologías Alternativas, Universidad Intercultural Indígena de Michoacán, Pichátaro, Michoacán, México \\ Corresponding Author: Ngangyo Heya Maginot \\ Email address: nheyamaginot@yahoo.fr
}

Background. The need for energy sources with low greenhouse gas emissions and sustainable production encourage the search for alternative biomass sources. However, the use of biomass fuels faces the problem of storage, transport and lower energy densities. Low-density values can negatively affect energy density, leading to an increase in transportation and storage costs. Use of pellets as alternative biomass source is a way to reduce the volume of biomass by densification, which improves their energy quality. They are produced by diverse biomass resources and mainly from wood materials. In all cases, it is important to evaluate the fuel characteristics, to determine their suitability on the heating system and handling properties.

Methods. The present study determines and compares data from proximate analysis, calorific values, physical and mechanical properties of wood pellets produced from the common tropical species Acacia wrightii, Ebenopsis ebano and Havardia pallens. Data were obtained from pellets produced from each species chips collected from an experimental plantation and analyzed through ANOVA and Kruskal-Wallis test at 0.05 significance level.

Results. The results of diameter, length and length/diameter ratio didn't show statistical differences ( $p$ $>0.05$ ) among species. Acacia wrightii showed the highest density $\left(1.2 \mathrm{~g} / \mathrm{cm}^{3}\right)$. Values on weight retained and compression test showed statistical differences $(p=0.05)$ among species. Havardia pallens was more resistant to compression strength than $A$. wrightii and Ebenopsis ebano. Statistical differences $(p<0.01)$ were also observed for the volatile matter and calorific value. $E$. ebano has the lowest volatile matter $(72 \%)$, highest calorific value $(19.6 \mathrm{MJ} / \mathrm{kg})$ as well as the fixed carbon $(21 \%)$.

Discussion. The pellets of the species studied have a high energy density, which makes them suitable for both commercial and industrial heating applications. A pellet with low compression resistance tends to disintegrate easily, due to moisture adsorption. The percentages obtained for the resistance index were higher than $97.5 \%$, showing that the pellets studied are high-quality biofuels. Proximate analysis values also indicate good combustion parameters. Pellets of Acacia wrightii and Ebenopsis ebano are the more favorable raw material sources for energy purposes because of their high density, calorific value, low ash content and they also met majority of the international quality parameters. 


\section{Physical, mechanical and energy characterization of wood pellets 2 obtained from three common tropical species}

3 Carrillo Parra Artemio ${ }^{1}$, Ngangyo Heya Maginot ${ }^{2}$,*, Colín-Urieta Serafín ${ }^{3}$, Foroughbakhch Pournavab

4 Rahim $^{2}$, Rutiaga Quiñones José Guadalupe ${ }^{3}$ and Correa-Méndez Fermín ${ }^{4}$

51 Universidad Juárez del Estado de Durango, Instituto de Silvicultura e Industria de la Madera, Boulevard del

6 Guadiana \#501. Ciudad Universitaria, Torre de Investigación, C.P. 34120, Durango, Dgo. México;

7 acarrilloparra@ujed.mx

82 Universidad Autónoma de Nuevo León, Facultad de Ciencias Biológicas, San Nicolás de los Garza, C.P. 66451.

9 Nuevo León, México; nheyamaginot@yahoo.fr, rahimforo@hotmail.com

103 Universidad Michoacana de San Nicolás de Hidalgo, Facultad de Ingeniería en Tecnología de la Madera,

11 Apartado Postal 580, C.P. 58030 Morelia, Michoacán, México; scuserafin@yahoo.com.mx , rutiaga@umich.mx

124 Universidad Intercultural Indígena de Michoacán, Desarrollo Sustentable, Tecnologías Alternativas, , Carretera

13 San Juan Tumbio - Cherán, Km. 16.2 Pichátaro, Michoacán; correa.mendez.fermin@gmail.com

$15 *$ Corresponding author:

16 Maginot Ngangyo Heya ${ }^{2}$

17 Email address: nheyamaginot@yahoo.fr

18 Tel.: +521-8120340601 
19 Abstract

20 Background. The need for energy sources with low greenhouse gas emissions and sustainable production encourages the search for alternative biomass sources. However, the use of biomass fuels faces the problem of storage, transport and lower energy densities. Low-density values can negatively affect energy density, leading to an increase in transportation and storage costs. Use of pellets as alternative biomass source is a way to reduce the volume of biomass by densification, which improves their energy quality. They are produced by diverse biomass resources and mainly from wood materials. In all cases, it is important to evaluate the fuel characteristics, to determine their suitability for the heating system and handling properties.

Methods. The present study determines and compares data from proximate analysis, calorific values, physical and mechanical properties of wood pellets produced from the common tropical species Acacia wrightii, Ebenopsis ebano and Havardia pallens. Data were obtained from pellets produced from chips of each species collected from an experimental plantation and analyzed through ANOVA and Kruskal-Wallis test at 0.05 significance level.

Results. The results of diameter, length and length/diameter ratio didn't show statistical differences $(\mathrm{p}>0.05)$ among species. Acacia wrightii showed the highest density $\left(1.2 \mathrm{~g} / \mathrm{cm}^{3}\right)$. Values on weight retained and compression test showed statistical differences $(p=0.05)$ among species. Havardia pallens was more resistant to compression strength than $A$. wrightii and Ebenopsis ebano. Statistical differences $(\mathrm{p}<0.01)$ were also observed for the volatile matter and calorific value. E. ebano has the lowest volatile matter (72\%), highest calorific value (19.6 MJ/kg) as well as fixed carbon $(21 \%)$.

Discussion. The pellets of the species studied have a high energy density, which makes them suitable for both commercial and industrial heating applications. A pellet with low compression resistance tends to disintegrate easily, due to moisture adsorption. The percentages obtained for the resistance index were higher than $97.5 \%$, showing that the pellets studied are high-quality biofuels. Proximate analysis values also indicate good combustion parameters.

Pellets of Acacia wrightii and Ebenopsis ebano are the more favorable raw material sources for energy purposes because of their high density, calorific value, low ash content and they also met majority of the international quality parameters. 


\section{Introduction}

The present society development provides increasing levels of comfort to the people, inevitably leading to an increase in energy consumption in all its forms (Van Duren et al., 2015), that require a constant and permanent supply (Song et al., 2015). It is estimated that $80 \%$ to $85 \%$ of the world's energy consumption is obtained directly from fossil fuels (BP, 2013), which cause greenhouse gas emissions, global warming, in addition they are limited in supply and they will eventually be depleted. Therefore, it is important to develop new energy policies, aimed at reducing the rate of energy consumption and the environmental impact associated with the use of fossil fuels.

Biomass is a clean source of energy whose use implies a reduction in the energy dependence of fossil fuels (Antolín, 2006). Thus, biomass energy is a promising alternative to such limited fossil fuel reserves as coal, oil and gas (Zhao et al., 2012), since the natural ecosystems produce more than 230 billion tons of biomass each year, of which only a quarter (24\%) is used to satisfy basic needs and industrial production, leaving $76 \%$ of the total biomass existing, which can therefore become a living "green" carbon source to supply or partially replace the "black" fossil fuels currently supporting the industrial economies (ETC-group, 2010). However, one of the challenges facing the energy industry is how to store the large quantities of biomass fuel required for thermal power plants (Craven et al., 2015). Moreover, biomasses are scattered resources with lower energy densities (Hu et al., 2014), and to be practical in large-scale applications, they must be first pretreated by grinding, drying and compressing (Chen et al., 2015), so that they are dry and dense with a higher energy density.

Densification then appears as a way of producing solid biofuels, easily transportable, manageable and storable, with optimum commercial quality. Densified biomass fuels such as pellets are preferred as they provide better economic viability for transport, storage and handling than other biofuels (Tauro et al., 2018). According to Patzek \& Pimentel (2007), they are easy to process, transport over long distances, and are relatively safe. Also, wood pellets are an efficient source of biomass energy, which is important, as fossil fuels contribute dramatically to $\mathrm{CO}_{2}$ emissions (Thomson \& Liddell, 2015), whereas pellets burn cleanly and thus create less air polluting emissions, as explained by Kowollik (2014) with the concept of neutral carbon, compared to other combustion heating energy sources. Many scientists and organizations believe if efforts to develop renewable energy continue, by 2050 renewable energy will provide about $30 \%$ 
80 of the world's demanded energy and a significant amount of this energy could come from wood 81 pellets (Guo et al., 2015), which are less expensive than fossil fuels, such as oil, liquefied 82 petroleum gas, and electric powered systems, particularly as wood pellets have higher energy 83 content than oil (Thomson \& Liddell, 2015). In addition, producing wood pellets is very cost84 effective since the raw materials are relatively cheap and mills can operate automatically needing 85 only a few employees (Lu \& Rice, 2010). These wood pellets' high availability and low price of raw materials make their cost more stable, which is especially positive as prices of fossil fuels fluctuate widely (Roh, 2016).

Thus, wood as a primary energy source, responds to available evidence and to a need for energy, especially relevant at the time of deep economic crisis, which has forced many to rethink future strategies (Brian et al., 2011). In this way, the use of wood pellets is a sustainable energy alternative (Mola-Yudego et al., 2014; Sgarbossa et al., 2015), that represents a positive globalization of wealth and local employment generation. This has resulted in soaring demand for wood pellets in Europe and North America (Heinimo \& Junginger, 2009), so that they are produced by diverse biomass resources, such as wood waste, energy forest and grape marc (Cespi et al., 2014; Dwivedi et al., 2014). Therefore, the pelletizing can be considered as an option to counteract the problem of excess waste normally generated in agro industrial and forestry activities (IRENA, 97 2013).

In tropical conditions, many agricultural and forestry crops are developed, generating a large amount of lignocellulosic waste (Ulloa et al., 2004), that could be used as fuel or energy source (Sekyere et al., 2004), through pelletization. However, before these woody pellets can be used, it is essential to first evaluate their fuel characteristics, taking as reference some standards, to ensure their uniformity, reducing market barriers and creating a product flow in which these biofuels can be traded between producers and users regardless of countries or regions (Cabral et al., 2012). This is directly related to the physical, mechanical and chemical properties that determine the quality of densified biomass during transportation and storage, as well as their energy capacity. Thus, in this study, three common tropical species are tested and characterized, to compare and determine the suitability of their pellets according to the international standards and end-user's requirements based on the heating system and handling properties. 


\section{Origin of raw materials and pellets production}

111 Four trees from each of the species Acacia wrightii, Ebenopsis ebano and Havardia pallens were

112 cut from an experimental plantation established in Northeast Mexico (Ngangyo-Heya et al., 2016).

113 The material was chipped, and then milled into a particle length lower than $4 \mathrm{~mm}$. The pellets were

114 produced in a press with compression channel length of $8 \mathrm{~mm}$ and channel diameter of $6 \mathrm{~mm}$,

115 without adding binder-additives to obtain pellet production of $400 \mathrm{~kg} / \mathrm{h}$. The pellets were cooled

116 and left in plastic bags at laboratory conditions for the physical and chemical tests.

\section{Physical properties}

118 The pelletizing press and wood particles characteristics affect pellets' physical properties such as

119 length, diameter and density. Pellet diameter is the result of the die dimension, and pellet length

120 from the distance between plate and knife placed down the dish, however particle density is related

121 to pelletizing conditions and wood particles characteristics. The pellets diameter and length was 122 measured for 50 samples of each species with a caliper, and the particle density was determined 123 by the ratio of mass to volume according to Equation 1. All values were the average of 50 samples 124 of each species.

$$
\mathrm{D}=\mathrm{m} / \mathrm{v}
$$

125 Where, $\mathrm{D}=$ Particle density $\left(\mathrm{g} / \mathrm{cm}^{3}\right), \mathrm{m}=$ Mass of pellet $(\mathrm{g}), \mathrm{V}=$ Volume of pellet $\left(\mathrm{cm}^{3}\right)$

\section{Mechanical properties}

127 Compression resistance at diametrical load was determined for 20 samples of each species, using

128 a Universal Testing Machine -Instron 300Dx, the pellet was placed between two flats and parallel 129 platens, and an increasing load was applied at the constant velocity of $2 \mathrm{~mm} / \mathrm{min}$ until the pellet 130 failed by cracking or braking according to the test established by Nielsen et al. (2009).

131 Impact resistance also known as "drop resistance" or "shattering resistance" was used to 132 determine the safe height of pellet production (Kaliyan \& Morey, 2009; Pietsch, 2008). The impact 133 resistance index (IRI) was obtained from the total number of pellets pieces produced after dropping 134 each of the 20 pellets per species four times from $1.8 \mathrm{~m}$ height. The data was calculated according 135 to Equation 2, developed by Richards (1990).

$$
I R I=100 \times \mathrm{N} / \mathrm{n}
$$


136 Where: $I R I=$ Impact resistance index, $N=$ Number of drops, $\mathrm{n}=$ Total number of pieces after the 137 four drops.

138 The retained weight percentage was determined from the weight of the total number of pellets

139 pieces produced from the four drops divided by the initial weight of the pellet multiplied by 100 140 according to Equation 3.

$$
R W=W n p / W N
$$

141 Where: $R W=$ Retained weight $(\%), W n p=$ Weight of the total pieces produced after four drops,

$142 W N=$ Weight of the initial piece of pellet.

\section{Proximate analysis and energy production}

144 Moisture content (\%), volatile matter (\%), and ash content (\%) were determined according to the 145 standards UNE-EN-14774-1 (2010), UNE-EN-15148 (2010), UNE-EN-14775 (2009), 146 respectively. Fixed carbon content was calculated by subtracting from the sum of the volatile 147 matter, moisture and ash content from 100. Gross calorific value of pellets was calculated 148 according to Equation 4 established by Parikh et al. (2005).

$$
G C V=0.3536 F C+0.1559 V M-0.0078 \mathrm{~A}
$$

149 Where, $G C V=$ Gross calorific value $(\mathrm{KJ} / \mathrm{kg}), F C=$ Fixed carbon $(\%), V M=$ Volatile matter $(\%)$, $150 A=\operatorname{Ash}(\%)$.

\section{Statistical analysis}

152 The data means and standard error values for the properties of the pellets produced from the three 153 species studied were determined, normality for all variables was corroborated by Shapiro-Wilk.

154 Data in percentage were transformed using the arc sine square root function to develop comparison 155 tests. Variables showing normal distribution were analyzed using one-way analysis of variance 156 (ANOVA) with a random arrangement. Comparisons with statistical differences $(\mathrm{p}<0.05)$ between 157 species, Tukey's honestly significant difference (HSD) tests were developed, this test consider 158 statistically significant at $\mathrm{p}<0.05$ for all pair-wise comparisons (Steel \& Torrie, 1960). For 159 variables non-normally distributed, comparisons among species were developed with Kruskal160 Wallis test. All statistical analyses were performed using the free $\mathrm{R}$ software, version 3.2.2 R 161 (Bolker, 2012). 


\section{Results}

\section{Physical properties}

164 The average and standard error of length, diameter and density of pellets produced with the 165 three tropical species studied are shown in Figure 1. Pellets density values showed statistical 166 differences $(\mathrm{p}<0.05)$ among species (Table 1). The density showed two statistical groups: (a) with 167 pellets of Acacia wrightii, which were the denser pellets $\left(1.18 \mathrm{~g} / \mathrm{cm}^{3}\right)$, and (b) constituted of pellets 168 obtained from Ebenopsis ebano and Havardia pallens that were statistically similar, with values 169 of 1.10 and $1.12 \mathrm{~g} / \mathrm{cm}^{3}$, respectively.

170 As for the dimensions, the pellets of the three species have similar diameters: A. wrightii $171(6.05 \pm 0.01 \mathrm{~mm})$, E. ebano $(6.03 \pm 0.01 \mathrm{~mm})$ and H. pallens $(6.07 \pm 0.01 \mathrm{~mm})$, while for the length, 172 the E. ebano pellets $(17.37 \pm 1.61 \mathrm{~mm})$ were longer than those of $A$. wrightii $(13.17 \pm 0.82 \mathrm{~mm})$ and 173 H. pallens $(13.44 \pm 0.99 \mathrm{~mm})$. The ratio length/diameter was $2.89 \pm 0.27,2.22 \pm 0.17$ and $2.17 \pm 0.14$ 174 for pellets of E. ebano, H. pallens and A. wrightii, respectively.

\section{Mechanical properties}

176 Compression resistance values showed statistical differences $(p<0.05)$ among species $($ Table 2). The bonds between pellet particles produced from Acacia wrightii wood chips were stronger than those from Ebenopsis ebano. Havardia pallens has the weakest particle bond (Figure 2).

The drop resistance index values for the three species ranges between 117 to 160. A. wrightii produced the most resistant pellets, while $H$. pallens produced less resistant pellets. The registered values did not show statistical differences $(\mathrm{p}>0.05)$ among species (Table 2$)$. Weight retained values showed statistical differences $(\mathrm{p}<0.05)$ among species (Table 2). Pellets of Acacia wrightii and Ebenopsis ebano were in the same statistical group "a" with values of 66.27 and 61.74, respectively, different from those of Havardia pallens in the statistical group "b", with the value of 49.49 (Figure 2).

\section{Proximate analysis and energy production}

Moisture content, volatile matter, fixed carbon and gross calorific value showed statistical differences $(\mathrm{p}<0.005)$ among species, while ash showed similar values among species (Table 3 ). The moisture content of all the pellets produced from the common tropical species tested was lower than $7 \%$, with E. ebano $(4.62 \pm 0.23 \%)$, H. pallens $(6.18 \pm 0.03 \%)$ and A. wrightii

$191(6.74 \pm 0.15 \%)$ as presented in Figure 3. Volatile matters oscillated from 72.25 to $79.38 \%$, values 
192 corresponding to pellets of E. ebano and H. pallens, respectively. The ash content ranged between

1932.41 to $3.22 \%$, being the smallest value obtained for pellets of $H$. pallens and the highest value for

194 pellets of $A$. wrightii. Fixed carbon varied significantly, with values ranging between 12 to $21 \%$,

195 thereby forming three statistical groups: "a" $H$. pallens $(12.03 \pm 0.11 \%)$, "b" A. wrightii

$196(13.44 \pm 0.51 \%)$ and "c" E. ebano (20.61 $1.01 \%)$. Calorific values found in this research were

197 higher than $17.8 \mathrm{MJ} / \mathrm{kg}$, and is the highest value obtained from pellets of E. ebano (19.64 MJ/kg).

\section{Discussion}

\section{Physical properties}

200 The values of pellets density obtained in this work are similar to $1.12-1.3 \mathrm{~g} / \mathrm{cm}^{3}$ reported in The Pellets Handbook by Thek and Obernberger (2012). Comparing wood density average,

202

203

204

205

206

207

208

209

210

211

212

213

214

215

216

217

218

219

220

Rodríguez et al. (2016) found that wood pellets density of A. wrightii, E. ebano and H. pallens increased $30 \%, 25 \%$ and $93 \%$, respectively, which confirm that pelletization is a good process to increase the density even to denser species. The bulk density of the input material is an important factor in pelleting as the mills are fed by volume rather than weight (Filbakk et al., 2011a). The consideration for this property is a good estimator of pellet quality for fuel applications, as it equates to more energy per unit volume, and means greater economy in fuel use, transportation and storage space (Rollinson \& Williams, 2016). Low density values can negatively affect the energy density causing an increase in transportation and storage costs. According to Obernberger and Thek (2006), the pellets of high energy density $\left(18-20 \mathrm{MJ} \mathrm{kg}^{-1}\right)$ are suitable for both commercial and industrial heating applications.

Comparisons between physical properties of pellets studied against values stated by standards CEN/TS 14961 (CEN/TS EN 14961-2, 2012), SS 187120 and CTI R04/05 showed that they met the standards (Duca et al., 2014). According to the CEN-EN 14961-1, pellets from the three species were "D 06" with a diameter of $6 \mathrm{~mm}$ and length between 3.15 to $40 \mathrm{~mm}$ (CEN/TS 14961, 2005). All pellets of the studied species are suitable for combustion in boilers with pneumatic feeding systems because their lengths were small enough to prevent a blockage in the mechanism. Also, the ratio of length and diameter was lower than maximum of five stated by Obernberger and Thek (2006) and ÖNORM (2000).

\section{Mechanical properties}


The compression resistance values of Acacia wrightii were within the range (295 to $692 \mathrm{~N}$ ) 222 reported by Tenorio et al. (2014) and Pampuro et al. (2017), while compression resistances of 223 pellets of Ebenopsis ebano and Havardia pallens were higher than the values reported. For wooden 224 pellets, the resistance to change from its original appearance is very important, since it indicates 225 how well they can resist external forces after a sustained period of use. This property is important 226 in the wood pellet industry and trade (Oveisi-Fordiie, 2011). A pellet with low compression 227 resistance is usually associated with problems such as difficulty in storage and shipping as well as 228 health and environmental issues. This is because such pellet has the tendency to disintegrate easily 229 due to moisture adsorption, fall or friction as reported by Temmerman et al. (2006). Thus, 230 measuring this parameter for pellets indicates their market values.

231 The values of the impact resistance index were higher than the ratio of 33 to $50 \%$ reported by 232 Forero-Nuñez et al. (2015). Pellets with a percentage higher than $97.5 \%$ as defined by ASABE 233 Standard S269.4 (2006), are considered a high quality biofuel because the particles have good 234 adhesion forces that allow pellets withstand transportation stress before reaching to the end users.

\section{Proximate analysis and energy production}

236 The moisture content of about 7\% for all the studied species is in conformity with Koppejan 237 and Van Loo (2012), who stipulated that moisture content of quality pellets should be lower than $23815 \%$. Moisture content values place the studied pellets as super premium $(\leq 8 \%)$, according to U.S. 239 standard which has other three lower grades, i.e., premium $(\leq 8 \%)$, standard $(\leq 10 \%)$ and utility $240(\leq 10 \%)$ (Tumuluru et al., 2010). Moisture content is a property that should be considered with 241 caution, since water has a crucial role in the pelletizing process (Samuelsson et al., 2009). A 242 number of studies on wooden pellets showed a positive correlation between MC and pellet 243 durability (Whittaker \& Shield, 2017), being this, one of the most important physical characteristic 244 of pellets. Higher MCs can reduce friction by lubricating the biomass (Nielsen et al., 2009), and 245 increase the extent at which pellets 'relax' after formation thereby leading to a decrease in 246 durability (Adapa et al., 2011). Water is not compressible, however, limiting the final density of 247 the pellet (Carone et al., 2011). When moisture content is at the level of $8.62 \%$, the maximum 248 durability of $96.7 \%$ can be reached (Colley et al., 2006). With MC of 8-15\%, there is an increase 249 in durability in Norway spruce and Scots pine (Lehtikangas, 2001). Filbakk et al. (2011b) also 250 found a positive correlation in durability ( $\mathrm{r} 2=0.62)$ with MC of $7-12 \%$ in Scots pine. Tulip wood 251 pellets showed the highest durability at a moisture content of 13\% (Lee et al., 2013). Across a 
252 range of biomass types including wood and straw, the optimum $\mathrm{MC}$ for pellet durability was 253 between 6.5 and 10.8\% (Miranda et al., 2015).

254 The volatile matters range (72 to 79\%) is in agreement with the results of Arranz et al. (2015), 255 Koppejan and Van Loo (2012), Tenorio et al. (2014), and are lower than 82.8\% reported by Chen 256 et al. (2015) for commercial pellets. The amount of volatile matters influences the behavior during 257 the combustion of solid fuels (Tauro et al., 2018) such that when volatile matters are high, the 258 biomass is considered a suitable fuel for thermal conversion (Olsson \& Kjällstrand, 2004; Holt et 259 al., 2006). Kataki and Konwer (2002) additionally indicated that high levels of volatile matters 260 produce a fast burning, a disadvantage to fuels.

261 Fixed carbon varied from 12 to $21 \%$, similar results were reported by Chen et al. (2015) and 262 Arranz et al. (2015). Fixed carbon has been reported to influence the gross calorific value (Tenorio 263 et al., 2014). Also, in relation to the potential of energy production, this property is the most 264 valuable parameter, since raw materials with high fixed carbon have higher heating values (Forero265 Nuñez et al., 2015).

266 The ash content ranged between 2.41 to $3.22 \%$, which is promising for the species studied. 267 Pellets with low ash contents are suitable for thermal conversion because they cause low ash 268 accumulation, slagging or corrosion in the boilers (Obernberger \& Thek, 2006; Rhén et al., 2007). Ashes reduce the quality of pellets, increase the emission of particles to the environment and reduce the heat value of biomass (Tumuluru et al., 2010). According to Uribe (1986), the higher the ash content in a solid fuel, the lower will be the heat obtained, causing problems with the handling and management of large quantities of ash produced. High ash content feedstock may also result in increase in maintenance cost for both household and industries users. The relatively small amount of ash indicates small ash forming elements, allowing the pellets to be used for industrial heating requirements, where problems associated with slagging, fouling and sintering formation are major concerns.

Gross calorific values found in this research were higher than $17.8 \mathrm{MJ} / \mathrm{kg}$, that are similar to the values reported by Telmo and Lousada (2011), indicating that pellet of the studied species are suitable to be used as feedstock (Laxamana, 1984; San Luis et al., 1984). Also, these values are within the minimum requirements of DIN 51731 (1996) for solid fuel, for industrial heating 281 processes. High gross calorific values allow the biofuel to produce a high amount of energy within low fuel volume (energy density) (Atuesta-Boada \& Sierra-Vargas, 2015). 


\section{Conclusions}

284 The wooden chips of the common tropical species Acacia wrightii, Ebenopsis ebano and Havardia 285 pallens from experimental plantations are suitable to produce pellets that meet the international 286 quality parameters. Pellets' physical parameters values such as length/diameter ratio and density 287 indicate a well bonding mechanism. Resistance, compression and weight retained values of the 288 three species guarantee that the pellets will produce low levels of fines during transportation. 289 Proximate analysis values indicate good combustion parameters for the species. Pellets of these 290 species are classified as M10 (moisture content lower than 10\%) and A0.5 (ash content lower than $2910.5 \%$ ). Gross calorific values from all the three species were higher than $17.8 \mathrm{MJ} / \mathrm{kg}$. From the 292 values of the wood pellets studied, Acacia wrightii and Ebenopsis ebano are the more favorable 293 raw materials sources for energy purposes, because of their high density, gross calorific value, low 294 ash content, that met the majority international quality parameters.

295

296

297

298

299

300

301

302

303

304

305

306

307

308

309

310

311

312

313

314

315

316

\section{References}

Adapa P, Tabil L, Schoenau G. 2011. Grinding performance and physical properties of non-treated and steam exploded barley, canola, oat and wheat straw. Biomass and Bioenergy, 35 (1): 549561.

Antolín G. 2006. La gestión y el aprovechamiento de los residuos en la industria de la madera, Maderas. Inst. Nac. Tecnol. Ind. Buenos Aires, Argentina. Cuad. Tecnológico. 29.

Arranz JI, Miranda MT, Montero I, Sepúlveda FJ, Rojas CV. 2015. Characterization and combustion behaviour of commercial and experimental wood pellets in South West Europe. Fuel, 142: 199-207.

ASABE Standards. 2006. S269.4: Cubes, pellets and crumbles-definitions and methods for determining density, durability and moisture content. American Society of Agricultural Engineers, St. Joseph, MI. ASAE

Atuesta-Boada LE, Sierra-Vargas FE. 2015. Caracterización físico-química de pellets producidos a partir de mezclas 50/50 carbón bituminoso/madera residual. Informador Técnico, [S.1.], v. 79,
n.
1. p.
$18-25$.
ISSN
2256-5035.
Available
on: http://revistas.sena.edu.co/index.php/inf tec/article/view/133/366 at: 01 nov. 2017. Doi: https://doi.org/10.23850/22565035.133.

Bolker B. 2012. R Development Core Team, bbmle: Tools for general maximum likelihood estimation. $\mathrm{R}$ package version, vol. $1, \mathrm{n}^{\circ} 5.2$.

BP. 2013. Statistical Review of World Energy. London, UK.

Brian Vad M, Lund H, Karlsson K. 2011. "100\% Renewable energy systems, climate mitigation and economic growth.” Applied Energy 88.2: 488-501. 
317 Cabral J, Tatiane D, Braga M, Mitiko M, Behling C, Dias P, Dilicio J. 2012. Produção de briquetes

318 e péletes a partir de resíduos agrícolas, agroindustrais e florestais. Brasil.

319 Carone MT, Pantaleo A, Pellerano A. 2011. Influence of process parameters and biomass

320 characteristics on the durability of pellets from the pruning residues of Olea europaea L.

321 Biomass and Bioenergy, 35 (1): 402-410

322 CEN/TS 14961. 2005. Solid biofuels, Fuel Specif. Classes. CEN/TS.

323 Cespi D, Passarini F, Ciacci L, Vassura I, Castellani V, Collina E, Piazzalunga A, Morselli L.

324 2014. Heating systems LCA: comparison of biomass-based appliances. The International

325 Journal of Life Cycle Assessment 19(1):89-99.

326 Chen WH, Peng J, Bi XT. 2015. A state-of-the-art review of biomass torrefaction, densification and applications. Renewable and Sustainable Energy Reviews. 44: 847-866.

Colley Z, Fasina OO, Bransby D, Lee YY. 2006. Moisture effect on the physical characteristics of switchgrass pellets. American Society of Agricultural and Biological Engineers 49(6): 1845-1851.

330

331

332

Craven JM, Swithenbank J, Sharifi VN, Peralta-Solorio D, Kelsall G, Sage P. 2015. Hydrophobic coatings for moisture stable wood pellets, Biomass and Bioenergy 80: 278-285.

333

DIN 51731. 1996. Testing of Solid Fuels-Compressed Untreated Wood, Requirements and Testing. Deutsches Institut fur Normung, Berlin.

335

336

Duca D, Riva G, Pedretti EF, Toscano G. 2014. Wood pellet quality with respect to EN 14961-2 standard and certifications. Fuel 135: 9-14.

337

Dwivedi P, Khanna M, Bailis R, Ghilardi A. 2014. Potential greenhouse gas benefits of transatlantic wood pellet trade. Environmental Research Letters 9(2).

339

ETC-group. 2010. Los nuevos amos de la biomasa. Biología sintética y el próximo asalto a la biodiversidad. Canadá: ETC-group.

Filbakk T, Høibø OA, Dibdiakova J, Nurmi J. 2011a. Modelling moisture content and dry matter loss during storage of logging residues for energy. Scandinavian Journal of Forest Research, 26 (3): 267-277.

344

345

Filbakk T, Skjevrak G, Høibø O, Dibdiakova J, Jirjis R. 2011b. The influence of storage and drying methods for Scots pine raw material on mechanical pellet properties and production parameters. Fuel Processing Technology, 92 (5): 871-878

Forero-Nuñez CA, Jochum J, Sierra FE. 2015. Effect of particle size and addition of cocoa pod husk on the properties of sawdust and coal pellets. Ingenieria E Investigación. 35: 17-23.

Guo M, Song W, Buhain J. 2015. Bioenergy and biofuels: History, status, and perspective. Renewable and Sustainable Energy Reviews, 712-725.

Heinimo J, Junginger M. 2009. Production and trading of biomass for energy - an overview of the global status. Biomass and Bioenergy 33:1310-20.

Holt GA, Blodgett TL, Nakayama FS. 2006. Physical and combustion characteristics of pellet fuel from cotton gin by-products produced by select processing treatments. Industrial Crops and Products. 24: 204-213. 
356

357

358

359

360

361

362

363

364

365

366

367

368

369

370

371

372

373

374

375

376

377

378

379

380

381

382

383

384

385

386

387

388

389

390

391

392

393

Hu J, Lei T, Wang Z, Yan X, Shi X, Li Z, He X, Zhang Q. 2014. Economic, environmental and social assessment of briquette fuel from agricultural residues in China a study on flat die briquetting using corn stalk. Energy 64:557-66.

IRENA. 2013. Renewable Power Generation Costs in 2012: An Overview. Bonn, Germany.

Kaliyan N, Morey RV. 2009. Factors affecting strength and durability of densified biomass products. Biomass and Bioenergy, 33: 337-359.

Kataki R, Konwer D. 2002. Fuelwood characteristics of indigenous tree species of north-east India. Biomass and Bioenergy 22: 433-437. doi: http://dx.doi.org/10.1016/S0961-9534(02)00026-0.

Koppejan J, Van Loo S. 2012. The handbook of biomass combustion and co-firing, Routledge.

Kowollik M. 2014. Costa Rica carbono neutral: un país pequeño con metas grandes. Perspectivas FES Costa Rica. $\mathrm{N}^{\circ} 8$.

Laxamana NB. 1984. Heating value of some Philippine woods, non-woods and barks. FPRDI Journal 8: 6-12.

Lee Sm, Ahn BJ, Choi DH, Han GS, Jeong HS, Ahn SH, Yang I. 2013. Effects of densification variables on the durability of wood pellets fabricated with Larix kaempferi C. and Liriodendron tulipifera L. sawdust. Biomass and Bioenergy, 48, pp. 1-9

Lehtikangas P. 2001. Quality properties of pelletised sawdust, logging residues and bark. Biomass and Bioenergy. 20: 351-360.

Lu N, Rice RW. 2010. Characteristics of Wood Fuel Pellet Manufacturers and Markets in the Unitied States, 2010. Forest Products Journal, 310-315.

Miranda T, Montero I, Sepúlveda F, Arranz J, Rojas C, Nogales S. 2015. A review of pellets from different sources. Materials 8 (4), p. 1413

Mola-Yudego B, Selkimaki M, Gonzalez-Olabarria JR. 2014. Spatial analysis of the wood pellet production for energy in Europe, Renew. Energy 63: 76-83.

Ngangyo-Heya M, Foroughbahchk-Pournavab R, Carrillo-Parra A, Rutiaga-Quiñones JG, Zelinski V, Pintor-Ibarra LF. 2016. Calorific value and chemical composition of five semi-arid Mexican tree species, Forests, 7(3), 58. doi:10.3390/f7030058.

Nielsen NPK, Holm JK, Felby C. 2009. Effect of Fiber Orientation on Compression and Frictional Properties of Sawdust Particles in Fuel Pellet Production, Energy \& Fuels, 23: 3211-3216.

Obernberger I, Thek G. 2006. Recent Developments concerning pellet combustion TechnologiesA Review of Austrian Developments.

Olsson M, Kjällstrand J. 2004. Emissions from burning of softwood pellets. Biomass and Bioenergy. 27: 607-611.

ÖNORM M. 2000. 7135: Compressed Wood or Compressed Bark in Natural State, Pellets and Briquettes, Requirements and Test Specifications, Österreichisches Normungsinstitut, Vienna, Austria.

Oveisi-Fordiie E. 2011. Durability of wood pellets. The University of British Columbia, Master of Science Thesis. $134 \mathrm{p}$. 
394 Pampuro N, Bagagiolo G, Priarone PC, Cavallo E. 2017. Effects of pelletizing pressure and the

395

396

397

398

399

400

401

402

403

404

405

406

407

408

409

410

411

412

413

414

415

416

417

418

419

420

421

422

423

424

425

426

427

428

429

430

431

432

433

addition of woody bulking agents on the physical and mechanical properties of pellets made from composted pig solid fraction. Powder Technology. 311: 112-119.

Patzek TW, Pimentel D. 2007. Thermodynamics of Energy Production from Biomass. Critical Reviews in Plant Sciences, 327-340.

Parikh J, Channiwala SA, Ghosal GK. 2005. A correlation for calculating HHV from proximate analysis of solid fuels. Fuel, 84: 487-494.

Pietsch WB. 2008. Agglomeration processes: phenomena, technologies, equipment, John Wiley $\&$ Sons.

Rhén C, Öhman M, Gref R, Wästerlund I. 2007. Effect of raw material composition in woody biomass pellets on combustion characteristics. Biomass and Bioenergy 31: 66-72.

Richards SR. 1990. Physical testing of fuel briquettes. Fuel Processing Technology, 25: 89-100.

Rodriguez HG, Maiti R, Kumari A, Sarkar NC. 2016. Variability in wood density and wood fibre characterization of woody species and their possible utility in northeastern Mexico. American Journal of Plant Sciences, 7(07):1139-1150. http://dx.doi.org/10.4236/ajps.2016.77109

Roh HB. 2016. Wood Pellets as a Biofuel: Current Status and their Market Potential. University of British Columbia. Series FRST 497. http://hdl.handle.net/2429/59204

Rollinson AN, Williams O. 2016. Experiments on torrefied wood pellet: study by gasification and characterization for waste biomass to energy applications. Royal Society Open Science. 3(5): 150578. doi:10.1098/rsos.150578.

Samuelsson R, Thyrel M, Sjöström M, Lestander TA. 2009. Effect of biomaterial characteristics on pelletizing properties and biofuel pellet quality. Fuel Processing Technology, 90 (9): 11291134.

San Luis JM, Briones LP, Estudillo CP. 1984. An evaluation of giant Ipil-ipil for charcoal production and briquetting. FPRDI Journal 8: 31-40.

Sekyere D, Okyere PY, Darkwah NA, Nketiah KS. 2004. Availability and Characteristics of Different Types of Wood Residue for Energy Production. Development of Energy Alternatives for the Efficient Utilization of Wood Processing Residue: Co-generation and Briquette Production, ITTO PROJECT PPD 53/02/ Rev.1 (I). Final Technical Report.

Sgarbossa A, Costa C, Menesatti P, Antonucci F, Pallottino F, Zanetti M, Grigolato S, Cavalli R. 2015. A multivariate SIMCA index as discriminant in wood pellet quality assessment, Renew. Energy 76: 258-263.

Song J, Song SJ, Oh SD, Yoo Y. 2015. Evaluation of potential fossil fuel conservation by the renewable heat obligation in Korea, Renew. Energy. 79: 140-149.

Steel RGD, Torrie JH. 1960. Principles and procedures of statistics. Princ. Proced. Stat.

Tauro R, García CA, Skutschc M, Masera O. 2018. The potential for sustainable biomass pellets in Mexico: An analysis of energy potential, logistic costs and market demand. Renewable and Sustainable Energy Reviews. 82: 380- 389. http://dx.doi.org/10.1016/j.rser.2017.09.036.

Telmo C, Lousada J. 2011. The explained variation by lignin and extractive contents on higher heating value of wood. Biomass and Bioenergy 35: 1663-1667. 
434 Temmerman M, Rabier F, Jensen PD, Hartmann H, Böhm T. 2006. Comparative study of

435

436

437

438

439

440

441

442

443

444

445

446

447

448

449

450

451

452

453

454

455

456

457

458

459

460

461

462 durability test methods for pellets and briquettes. Biomass and Bioenergy 30: 964-972

Tenorio C, Moya R, Tomazello-Filho M, Valaert J. 2014. Quality of pellets made from agricultural and forestry crops in Costa Rican tropical climates, BioResources. 10: 482-498.

Thek G, Obernberger I. 2012. The pellet handbook: the production and thermal utilization of biomass pellets, Routledge.

Thomson H, Liddell C. 2015. The suitability of wood pellet heating for domestic households: A review of literature. Renewable and Sustainable Energy Reviews, 1362-1369.

Tumuluru JS, Sokhansanj S, Lim CJ, Bi T, Lau A, Melin S, Oveisi E. 2010. Quality of wood pellets produced in British Columbia for export. In Annual Meeting as Paper No 9, 7265. Paris, France

Ulloa JB, Weerd JH, Huisman EA, Verreth JA. 2004. Tropical agricultural residues and their potential uses in fish feeds: the Costa Rica situation. Waste Management, 24 (1): 87-97.

UNE-EN 15148. 2010. Biocombustibles sólidos. Determinación del contenido en materias volátiles.

UNE-EN-14774. 2010. Biocombustibles sólidos. Determinación del contenido de humedad. Método de secado en estufa., Madrid, España Asoc. Española Norm. Y Certificación. Parte 3. $\mathrm{H}$.

UNE-EN-14775. 2009. Biocombustibles sólidos. Método para la determinación del contenido en cenizas.

Uribe BCA. 1986. Introducción a la Tecnología del Carbón: Origen, Composición, Propiedades, Clasificación. - Informe No 1980. Ingeominas, Bogotá

Van Duren I, Voinov A, Arodudu O, Firrisa MT. 2015. Where to produce rapeseed biodiesel and why? Mapping European rapeseed energy efficiency. Renewable Energy. 74: 49-59.

Whittaker C, Shield I. 2017. Factors affecting wood, energy grass and straw pellet durability. A review. Renewable and Sustainable Energy Reviews. Vol. 71: 1-11. https://doi.org/10.1016/j.rser.2016.12.119

Zhao X, Wang J, Liu X, Liu P. 2012. China's wind, biomass and solar power generation: what the situation tells us? Renewable \& Sustainable Energy Reviews. 16(8), 6173-82. 


\section{Table $\mathbf{1}$ (on next page)}

Shapiro-Wilk and Kruskal-Wallis tests of the physical properties of pellets elaborated from chips of three common tropical species. Value highlighted bold indicated statistical differences $(p<0.05)$ among species 


\begin{tabular}{lccccc}
\hline \multirow{2}{*}{\multicolumn{1}{c}{ Physical property }} & \multicolumn{2}{c}{ Shapiro-Wilk test } & \multicolumn{2}{c}{ Kruskal-Wallis test } \\
\cline { 2 - 5 } & Statistic & p-value & chi-squared & p-value \\
\hline Diameter & 0.79371 & $2.90 \mathrm{E}-13$ & 2.5197 & 0.2837 \\
Length & 0.88039 & $1.19 \mathrm{E}-09$ & 1.4084 & 0.4945 \\
Ratio Length/Diameter & 0.90761 & $3.64 \mathrm{E}-08$ & 1.4516 & 0.4839 \\
Density & 0.94534 & $1.37 \mathrm{E}-05$ & $\mathbf{9 . 1 3 4 3}$ & $\mathbf{0 . 0 1 0 4}$ \\
\hline
\end{tabular}




\section{Table 2 (on next page)}

Shapiro-Wilk and Kruskal-Wallis tests of the mechanical properties of pellets elaborated from chips of three common tropical species. Bold data shows the variable with statistical differences $(p<0.05)$ among species 
1

\begin{tabular}{l|r|r|r|r}
\hline \multirow{2}{*}{ Mechanical property } & \multicolumn{2}{c}{ Shapiro-Wilk test } & \multicolumn{2}{c}{ Kruskal-Wallis test } \\
& Statistic & p-value & chi-squared & \multicolumn{1}{c}{ p-value } \\
\hline Compression & 0.95677 & $3.28 \mathrm{E}-02$ & $\mathbf{1 4 . 8 6 8}$ & $\mathbf{0 . 0 0 0 5 9 0 9}$ \\
Drop resistance & 0.69085 & $5.94 \mathrm{E}-10$ & 3.9705 & 0.1373 \\
Weigth retained & 0.95128 & $1.79 \mathrm{E}-02$ & $\mathbf{7 . 7 0 5 9}$ & $\mathbf{0 . 0 2 1 2 2}$ \\
\hline
\end{tabular}

2 


\section{Table 3(on next page)}

Shapiro-Wilk and Kruskal-Wallis tests of the proximate analysis and energy values of pellets elaborated from chips of three common tropical species. Bold data shows the variable with statistical differences $(p<0.05)$ among species. 


\begin{tabular}{lcrrrrr}
\hline \multirow{2}{*}{$\begin{array}{c}\text { Proximate analysis and } \\
\text { energy values }\end{array}$} & \multicolumn{2}{c}{ Shapiro-Wilk test } & \multicolumn{2}{c}{ Kruskal-Wallis test } & \multicolumn{2}{c}{ Anova test } \\
Statistic & p-value & chi-squared & p-value & F value & p-value \\
\hline Moisture content & 0.92759 & $\mathbf{0 . 4 5 8 8}$ & & & $\mathbf{3 2 . 4 0}$ & $\mathbf{0 . 0 0 0 6 0 9}$ \\
Volatile matter & $\mathbf{0 . 9 3 7 5 2}$ & $\mathbf{0 . 5 5 6}$ & - & - & $\mathbf{5 9 . 1 2}$ & $\mathbf{0 . 0 0 0 1 1 3}$ \\
Ash & $\mathbf{0 . 9 6 3 8 1}$ & $\mathbf{0 . 8 3 7 3}$ & - & - & 1.764 & 0.25 \\
Fixed carbon & 0.82073 & 0.03512 & & $\mathbf{7 . 2}$ & $\mathbf{0 . 0 2 7 3 2}$ & - \\
Gross calorific value & $\mathbf{0 . 8 3 7 4 8}$ & $\mathbf{0 . 0 5 4 1 5}$ & - & - & $\mathbf{2 3 . 1 4}$ & $\mathbf{0 . 0 0 1 5 1}$ \\
\hline
\end{tabular}


Figure 1 (on next page)

Average and standar error of lengh, diameter, ratio length/diameter and particle density of wood pellets produced from three common tropical species.

Density of species with the same letters are statistically similar $(p<0.05)$ according to Tukey's honestly significant difference test 


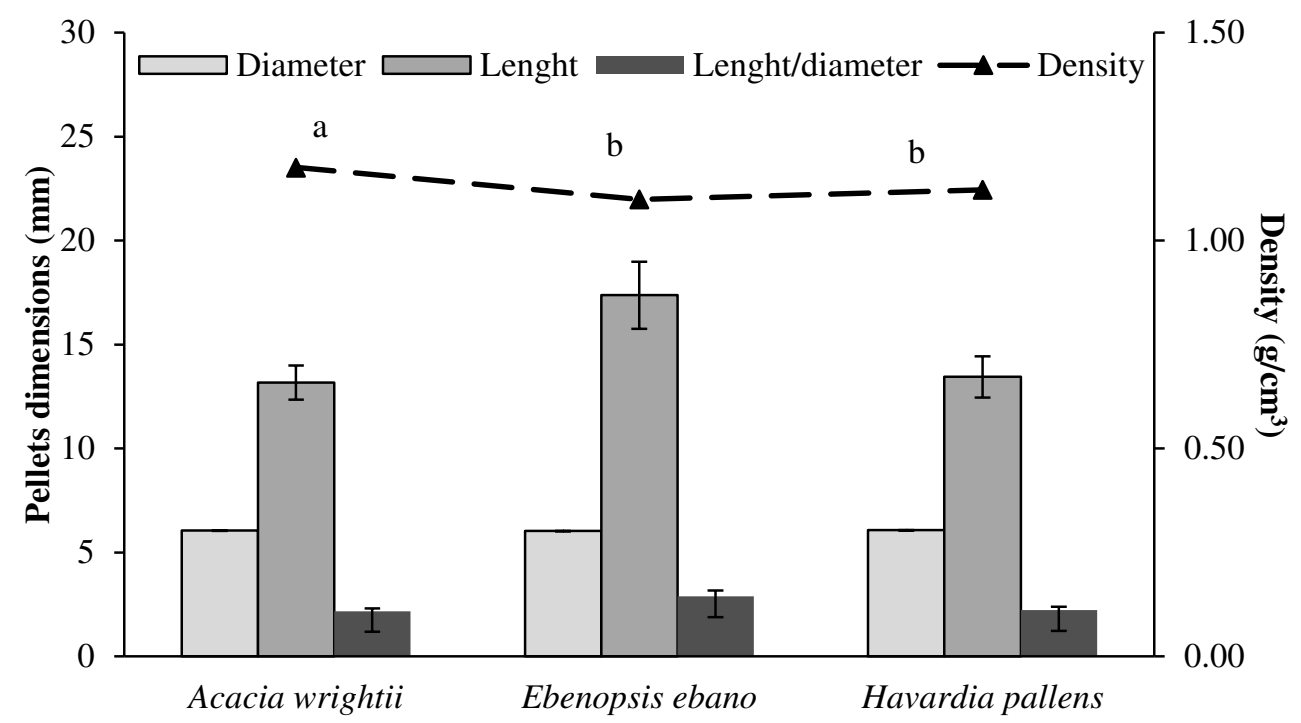




\section{Figure 2 (on next page)}

Average and standard error of drop resistance, weight retained and compression resistance of wood pellets produced from three common tropical species

Weight retained and compression resistance values of species with the same letters are statistically similar $(p<0.05)$ according to Kruskal test 


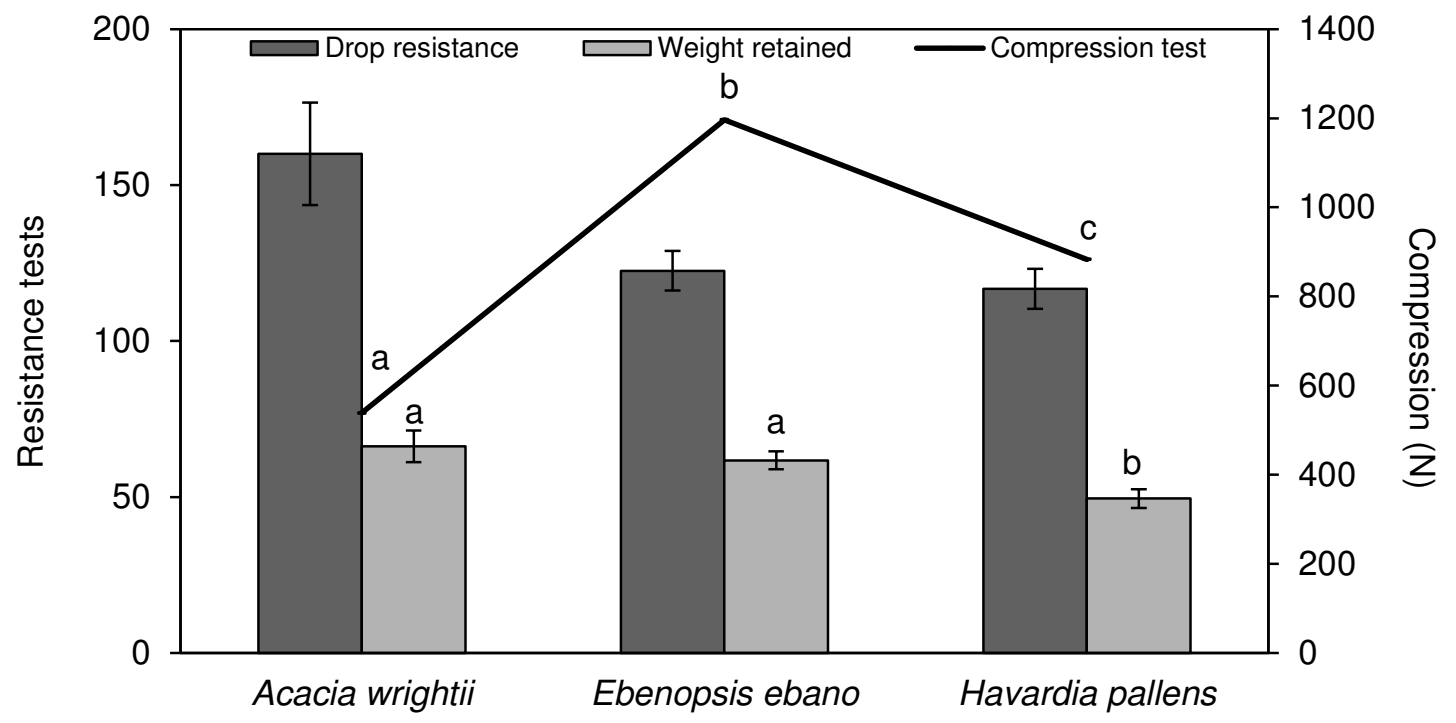


Figure 3 (on next page)

Proximate analysis and energy values of wood pellets from three tropical species.

Moisture content, volatile material and gross calorific values of species with the same letters are statistically similar $(p<0.05)$ according to Tukey's honestly significant difference test, and by fixed carbon values is according to Kruskal test 


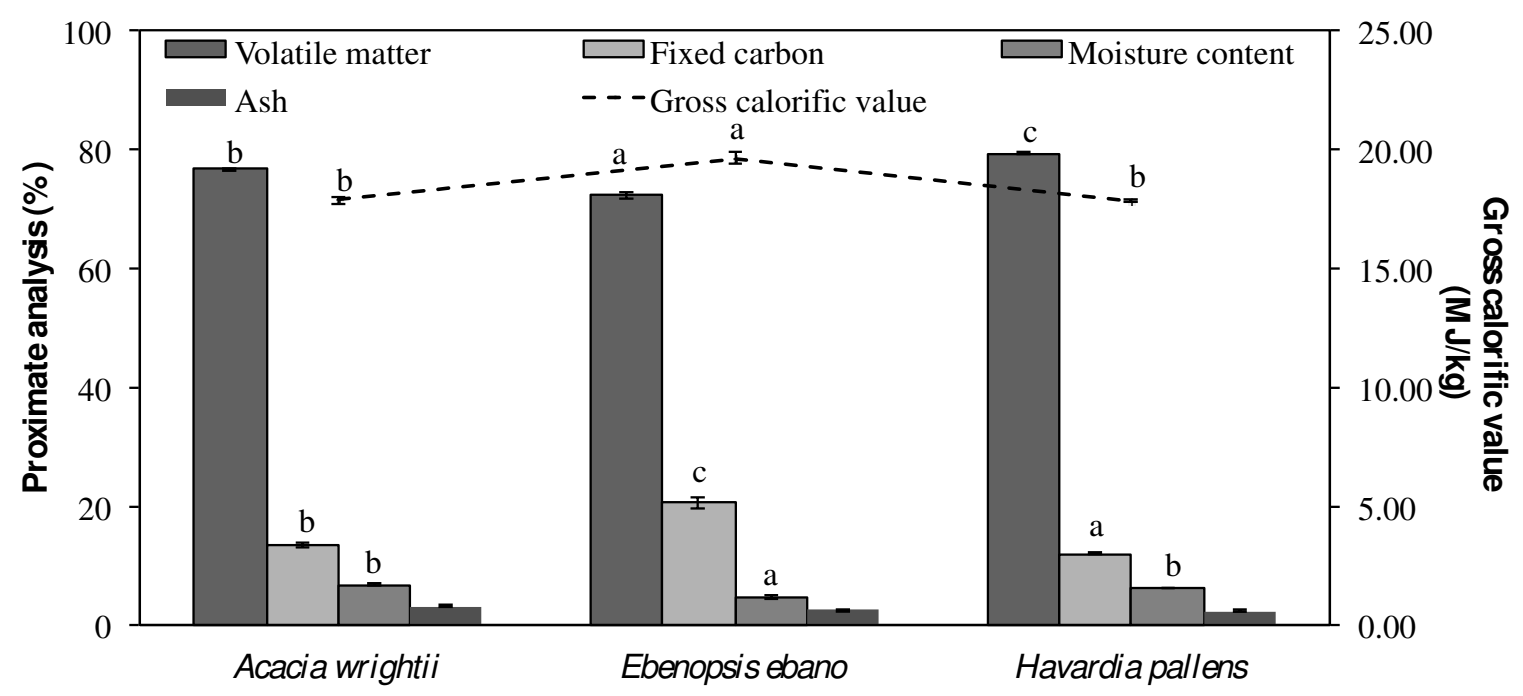

